\title{
Effect of Various Pretreatments on Raisin Making from Grapes (Vitis vinifera L.)
}

\author{
N.R. Sardar*, Tiwari Manish, G.P. Tagalpallewar, J.P. Rathod and Butti Prabhakar \\ College of Food Processing Technology and Bioenergy, Anand Agricultural University \\ Anand-388110 Gujarat-India \\ *Corresponding author
}

\section{A B S T R A C T}

\begin{tabular}{|l|}
\hline Ke y w o r d s \\
Grape, Raisins, \\
Pretreatment, \\
Drying, \\
Organoleptic \\
properties
\end{tabular}

Grapes are good source of dietary sugars, organic acids and provide good amount of minerals like iron and phosphorus and some vitamins. Among the grape processed products raisins are one of the most important processed products obtained from grapes. The mature, clean and uniform size green grape berries (Thompson seedless) were taken. The berries were treated by using different methods viz. Preyal dip, Australian dip and soda dip. Drying was done at 50 and $60^{\circ} \mathrm{C}$ to study the effect of drying temperature on quality of raisin. The grape berries were dried from 78 per cent (345.54 per cent, d.b.) to 13.14 per cent (15.15 per cent, d.b.). The total drying time of 60 to $96 \mathrm{hrs}, 40$ to $51 \mathrm{hrs}, 60$ to $78 \mathrm{hrs}$, and 60 to $80 \mathrm{hrs}$ was required for control sample, Australian cold dip, soda dip, preyal dip methods respectively. The drying rate varied between 26.04 to $0.12 \mathrm{~g} / \mathrm{hr}$ $100 \mathrm{gd}$. b.m. for all treatments. The average score for color, appearance, texture and taste of the raisins ranged between 5.6 to $8.6,5.5$ to 8.3 and 5.2 to8.1 respectively. The overall acceptability of the raisins made by using Australian cold dip, preyal dip, soda dip and control methods was found as 8.3,8.0,7.1 and 6.5 when grapes were dried at $50^{\circ} \mathrm{C}$. The minimum overall acceptability of the raisins made by using Australian cold dip, preyal dip, soda dip and control methods was found as 7.4, 6.8, 6.2 and 5.4 when grapes were dried at $60^{\circ} \mathrm{C}$. The better quality raisins could be prepared from the grapes using Australian cold dip method at drying temperature $50^{\circ} \mathrm{C}$. Drying characteristics and organoleptic properties of raisins prepared by different methods the Australian cold dip method was found to be suitable for preparation of raisins.

\section{Introduction}

Grape (Vitis vinifera L.) is one of the most diffuse fruit in the world both as fresh fruit (table grape) and processed in wine, grape juice, molassa and rainsins. Grape occupies $2.21 \%$ total area under fruit cultivation. India grape production is 12.0 lacks tones and area under cultivation is 0.43 lacks ha. Grapes are grown in the states of Maharashatra, Karnataka, Andhra Pradesh, Punjab, Tamilnadu. In Maharashtra various varieties are available. Some of them are Thompson seedless, sharad seedless, Aneb-e-shahi, Arkavati, Pusa seedless. The grape is cultivated in large scale in three districts of 
Maharashtra viz Nashik, Pune and Sangali. However it is proposed to be expanded in Ahmednagar, Solapur, Usmanabad, and Latur. Also each of which has more than 500 ha under grapes. Thus the project is proposed to be implemented in all the seven districts. However the grape cultivation can be extended to the other non traditional districts also (Anonymous, 2003). The reason to have these different proposed products depends on the extreme perishability of the fruit. As fresh fruit grapes are very delicate and the loss at harvest and during the distribution is very high. About $85 \%$ of the total production is used for table purpose and remaining is used for raisin, wines and beverages and also in medical formulation (Shikhamany, 2004). Raisin is one of the important processed product obtained from grapes. Raisins are prepared mainly from seedless grapes. In India both seedless and seeded varieties are used for raisin making. The Seeded raisins called as 'Manuka' are used for their therapeutic value; while seedless raisins known as 'Kishmish' are used at festive occasions both religious and social. The Commonly used method for raisin making preparation in Maharashtra is cold dip followed by sulfur fumigation in some cases. It is more convenient and suitable than hot dip method (Ambadan, 1985). Raisin not only provide sweetness but are excellent source of dietary fibers 5.9 percent, broken down into a soluble non cellulose polysaccharide content of 59.3 percent and an insolubic non cellulose polysaccharide and cellulose content of 10 per cent and 30.7 percent respectively. Raisin also have some flavor enhancing capacity due to their 2.2 per cent tartaric acid level and content reducing sugar which acts as precursors of the mallard reaction, the process that causes non enzymatic browning. Raisin is also good source of vitamin and minerals, as are other fruits. Raisin not only provides great flavor appeal and versatility, but health attributes as well (Anonymous, 2000).
However pre drying treatment facilitates easy removal of moisture and drying at grapes berries to a specific moisture level. Seven chemicals have been used singly or in combinations for pre drying treatments. These include sodium hydroxide, potassium carbonate, sulpher, citric acid, potassium metabisulphite (kms), sugar syruping etc (Amba Dan, 1985).

\section{Materials and Methods}

The berries were treated by using different methods viz. Preyal dip, Australian dip and soda dip as pre-treatment. Drying was done at 50 and $60^{\circ} \mathrm{C}$ to study the effect of drying temperature on quality of raisin. Moisture content, drying rate, organoleptic characteristics viz. color, appearance, texture, taste and overall acceptability are dependant variables.

\section{Sample preparation}

Commercial black cultivar, Thompson Seedless grapes were obtained from the farm of Mr. J.D. Kedar of Kathargaon, Dist. Nasik. All the fruits were harvested when they attend full physiological maturity. The uniformly ripe clusters containing berries of uniform size, shape, color and bloom were selected for experiments. The bunches were harvested from randomly selected three different vines, each serving as on replication. Immediately after harvested the grape bunched were packed in corrugated fiber boxes and brought to the laboratory. They were stored in a refrigerator until used for experimental work. Preliminary experiments were conducted to select suitable method for preparation of raisins. Based on this raisins were prepared by three different methods Viz. Preyal Dipping, Australian cold dip, and soda dip method. The grape berries were separated from the clusters. All diseased, cracked, malformed and discolored berries were sorted out and 
discarded. The berries were thoroughly washed under tap water for removal of adhering dust and foreign matter. For each method half $\mathrm{kg}$ grapes of Thompson seedless cultivar were used in triplicate sets.

\section{Pre treatments}

Control (To) Grapes were dried in a tray drier without pre treatment till the moisture content was reduced to about 14 per cent. Preyal dip method $\left(\mathrm{T}_{1}\right)$ Solution containing 2.4 per cent potassium carbonate and 1.5 per cent preyal dipping oil was prepared. Grapes were kept in tray dryer for drying at 50 and $60^{\circ} \mathrm{C}$ without dipping. After 50 per cent reduction in wet of water two third concentration of above solution was sprayed. After 75 per cent reduction in weight of water one third concentration was applied. They were then dried till the moisture content reduced to about 14 per cent. Australian cold dip method $\left(\mathrm{T}_{2}\right)$ solution containing 5 per cent potassium carbonate and 0.4 per cent olive oil at $45^{\circ} \mathrm{C}$ was prepared. Grapes were dipped in these solutions for three minutes. They were then dried in the tray drier till moisture content was reduced to about 14 per cent. Soda dip method $\left(\mathrm{T}_{3}\right)$ Grapes were dipped in 0.3 per cent sodium hydroxide solution at $100^{\circ} \mathrm{C}$ for three seconds and immediately rinsed in cold water. After rinsing they were dried at in 50 and $60^{\circ} \mathrm{C}$ tray drier till the moisture content reduced to about 14 per cent.

\section{Results and Discussion}

The data on effect of pretreatment, drying temperature, drying time on moisture content of grapes is tabulated in Table 1 (control), Table 2 (Australian cold dip), Table 3 (soda dip) and Table 4 (preyal dip) for all drying temperatures. The moisture content varied between 333.8 to 14.42 percent for all the pretreatments. The moisture content decreased with increased in drying time for all drying temperatures. The maximum decrease in moisture content was found in drying temperature $60^{\circ} \mathrm{C}$ compared to other drying temperature.

The drying time of 40 to $62 \mathrm{hrs}$ and 45 to 85 hrs were required obtained for drying of grapes using all pretreatments at $50^{\circ}$ and $60^{\circ} \mathrm{C}$ respectively. Similar trend were reported by More and Pagare (1998). The minimum drying time of 40 to $51 \mathrm{hrs}$ was recorded in case of Australian cold dip method at all temperatures. Whereas maximum drying time 62 to $96 \mathrm{hrs}$ was required in control samples. The drying time of 60 to $80 \mathrm{hrs}$ was recorded in case of soda and preyal dip methods at all drying temperatures. Dipping oil helped to remove upper waxy cover on the grape berry. This enhanced the moisture removal. Whereas control samples requires maximum time because intact berry surface obstruct rapid moisture removal. Similar results were obtained by Gawade et al., (1994). The grape berries treated with Australian cold dip were dried within 40 to 45 hrs when dried at $60^{\circ}$ and $50^{\circ} \mathrm{C}$ respectively.

\section{Effect of pre treatment, drying temperature and time on drying rate}

The drying data is plotted and shown in Fig. 6 to 9 . The drying rate varied between 26.04 to $0.12 \mathrm{~g} / \mathrm{hr}-100 \mathrm{~g}$ b.d.m. For all the pretreatments, all the curves were exponential. The drying rate decreased with increase in drying time for all drying temperatures.

It revealed that at the initial stage of drying, the drying rates were maximum and then it decreased with drying time. The drying rates became constant in the final stage of drying at all drying temperatures. The maximum drying rate was found in case of drying temperature of 6oc compared to other drying temperature for all the pretreatments (Fig. 6 to 9). The 
drying rate of 26.04 to 0.27 and 24.56 to 0.20 $\mathrm{g} / \mathrm{hr}-100 \mathrm{~g}$ b.d.m. were obtained for drying of grapes using all pretreatments at $60^{\circ} \mathrm{C}, 50^{\circ} \mathrm{C}$ respectively.

The maximum drying rate (20.55 to 26.04 $\mathrm{g} / \mathrm{hr}-100 \mathrm{~g}$ b.d.m.) was seen in case of Australian dip method at all drying temperatures whereas minimum drying rate was seen in case of control samples.

The drying rates were found to be higher for all treated samples as compared to control samples at all drying temperatures. Drying rate of preyal dip and soda dip grapes were found to be in between Australian dip and control sample at all drying temperatures. Oil dipped and soda treated samples showed higher drying rate as compared to control samples.

This may be attributed to waxy cover removal and production of cracks due to dipping and alkali treatment respectively. Similar results were obtained by Gee (1980). The Australian dipped grapes showed 26.04 to 0.27 and 24.56 to $0.20 \mathrm{~g} / \mathrm{hr}-100 \mathrm{~g}$ b.d.m. Drying rate when dried at $50^{\circ} \mathrm{C}$ and $60^{\circ} \mathrm{C}$.

Table.1 Drying data for without treatment

\begin{tabular}{|c|c|c|c|c|c|c|}
\hline \multicolumn{7}{|c|}{ Drying data for without treatment at $\mathbf{5 0}^{\mathbf{0}} \mathbf{C}$} \\
\hline Sr. No. & $\begin{array}{c}\text { Drying } \\
\text { time(hr) }\end{array}$ & $\begin{array}{c}\text { Weight of } \\
\text { sample(g) }\end{array}$ & $\begin{array}{c}\text { M.C. } \\
\text { (w.b.) }\end{array}$ & $\begin{array}{c}\text { M.C. } \\
\text { (d.b.) }\end{array}$ & $\begin{array}{c}\text { Drying } \\
\text { rate }\end{array}$ & $\begin{array}{c}\text { Moisture } \\
\text { ratio }\end{array}$ \\
\hline 1 & 0 & 100.00 & 78.00 & 345.54 & - & 1.000 \\
\hline 2 & 5 & 77.34 & 65.43 & 189.23 & 17.04 & 0.570 \\
\hline 3 & 10 & 60.02 & 55.45 & 124.48 & 13.02 & 0.359 \\
\hline 4 & 15 & 52.70 & 49.26 & 97.08 & 5.50 & 0.269 \\
\hline 5 & 20 & 47.52 & 43.73 & 77.71 & 3.86 & 0.206 \\
\hline 6 & 30 & 41.20 & 35.10 & 54.08 & 2.86 & 0.129 \\
\hline 7 & 40 & 34.80 & 25.35 & 33.69 & 1.34 & 0.063 \\
\hline 8 & 60 & 30.10 & 18.23 & 22.29 & 0.81 & 0.026 \\
\hline 9 & 62 & 29.40 & 16.80 & 20.19 & 0.56 & 0.019 \\
\hline 10 & 80 & 27.60 & 13.80 & 16.01 & 0.34 & 0.005 \\
\hline 11 & 85 & 26.64 & 12.60 & 14.42 & 0.20 & 0.000 \\
\hline
\end{tabular}

\begin{tabular}{|c|c|c|c|c|c|c|}
\hline \multicolumn{7}{|c|}{ Drying data for without treatment at $\mathbf{6 0}^{\mathbf{0}} \mathbf{C}$} \\
\hline Sr. No & $\begin{array}{c}\text { Drying } \\
\text { time(hr) }\end{array}$ & $\begin{array}{c}\text { Weight of } \\
\text { sample(g) }\end{array}$ & $\begin{array}{c}\text { M.C. } \\
\text { (w.b.) }\end{array}$ & $\begin{array}{c}\text { M.C. } \\
\text { (d.b.) }\end{array}$ & $\begin{array}{c}\text { Drying } \\
\text { rate }\end{array}$ & $\begin{array}{c}\text { Moisture } \\
\text { ratio }\end{array}$ \\
\hline 1 & 0 & 100.00 & 78.00 & 345.54 & & 1.000 \\
\hline 2 & 5 & 72.56 & 63.34 & 172.78 & 20.52 & 0.511 \\
\hline 3 & 10 & 59.24 & 52.70 & 111.43 & 12.21 & 0.312 \\
\hline 4 & 15 & 46.60 & 42.92 & 75.19 & 7.21 & 0.194 \\
\hline 5 & 20 & 41.80 & 37.26 & 59.40 & 3.14 & 0.143 \\
\hline 6 & 30 & 36.46 & 27.04 & 37.07 & 2.68 & 0.071 \\
\hline 7 & 40 & 30.30 & 20.20 & 25.31 & 0.71 & 0.033 \\
\hline 8 & 60 & 27.10 & 13.50 & 15.61 & 0.42 & 0.001 \\
\hline 9 & 62 & 26.11 & 13.20 & 15.21 & 0.27 & 0.000 \\
\hline
\end{tabular}


Table.2 Drying data for Australian dip treatment

\begin{tabular}{|c|c|c|c|c|c|c|}
\hline \multicolumn{7}{|c|}{ Drying data for Australian dip treatment at $50^{\mathbf{0}} \mathbf{C}$} \\
\hline Sr. No & $\begin{array}{c}\text { Drying } \\
\text { time(hr) }\end{array}$ & $\begin{array}{c}\text { Weight of } \\
\text { sample(g) }\end{array}$ & $\begin{array}{c}\text { M.C. } \\
(\mathbf{w . b .})\end{array}$ & $\begin{array}{c}\text { M.C. } \\
\text { (d.b.) }\end{array}$ & $\begin{array}{c}\text { Drying } \\
\text { rate }\end{array}$ & $\begin{array}{c}\text { Moisture } \\
\text { ratio }\end{array}$ \\
\hline 1 & 0 & 100.00 & 78.00 & 345.54 & & 1.000 \\
\hline 2 & 5 & 66.01 & 60.34 & 152.14 & 24.56 & 0.431 \\
\hline 3 & 10 & 52.04 & 49.80 & 99.20 & 10.75 & 0.264 \\
\hline 4 & 15 & 44.67 & 42.00 & 72.41 & 5.44 & 0.180 \\
\hline 5 & 20 & 39.70 & 32.70 & 48.59 & 4.43 & 0.105 \\
\hline 6 & 25 & 35.80 & 25.70 & 34.59 & 2.30 & 0.081 \\
\hline 7 & 30 & 33.30 & 21.30 & 27.06 & 1.67 & 0.037 \\
\hline 8 & 35 & 31.20 & 18.00 & 21.95 & 1.36 & 0.021 \\
\hline 9 & 40 & 28.50 & 15.00 & 17.65 & 0.67 & 0.007 \\
\hline 10 & 45 & 27.44 & 13.30 & 15.34 & 0.37 & 0.000 \\
\hline
\end{tabular}

\begin{tabular}{|c|c|c|c|c|c|c|}
\hline \multicolumn{7}{|c|}{ Drying data for Australian dip treatment at 60 C } \\
\hline Sr. No & $\begin{array}{c}\text { Drying } \\
\text { time(hr) }\end{array}$ & $\begin{array}{c}\text { Weight of } \\
\text { Sample(g) }\end{array}$ & $\begin{array}{c}\text { M.C. } \\
\text { (w.b.) }\end{array}$ & $\begin{array}{c}\text { M.C. } \\
(\mathbf{d . b .})\end{array}$ & $\begin{array}{c}\text { Drying } \\
\text { rate }\end{array}$ & $\begin{array}{c}\text { Moisture } \\
\text { ratio }\end{array}$ \\
\hline 1 & 0 & 100.00 & 78.00 & 345.54 & & 1.000 \\
\hline 2 & 5 & 63.79 & 56.95 & 132.29 & 26.04 & 0.363 \\
\hline 3 & 10 & 50.09 & 43.73 & 77.71 & 11.81 & 0.194 \\
\hline 4 & 15 & 42.20 & 34.90 & 53.61 & 6.23 & 0.120 \\
\hline 5 & 20 & 36.00 & 26.80 & 36.61 & 2.43 & 0.067 \\
\hline 6 & 25 & 32.60 & 20.50 & 25.79 & 2.02 & 0.034 \\
\hline 7 & 30 & 30.30 & 17.10 & 20.63 & 1.05 & 0.018 \\
\hline 8 & 35 & 28.00 & 14.70 & 17.23 & 0.79 & 0.007 \\
\hline 9 & 40 & 26.68 & 12.92 & 14.84 & 0.51 & 0.000 \\
\hline
\end{tabular}


Table.3 Drying data for Soda dip treatment

\begin{tabular}{|c|c|c|c|c|c|c|}
\hline \multicolumn{7}{|c|}{ Drying data for Soda dip treatment at $\mathbf{5 0}^{\mathbf{0}} \mathbf{C}$} \\
\hline Sr. No & $\begin{array}{c}\text { Drying } \\
\text { time(hr) }\end{array}$ & $\begin{array}{c}\text { Weight of } \\
\text { sample(g) }\end{array}$ & $\begin{array}{c}\text { M.C. } \\
\text { (w.b.) }\end{array}$ & $\begin{array}{c}\text { M.C. } \\
\text { (d.b.) }\end{array}$ & $\begin{array}{c}\text { Drying } \\
\text { rate }\end{array}$ & $\begin{array}{c}\text { Moisture } \\
\text { ratio }\end{array}$ \\
\hline 1 & 0 & 100.00 & 78.00 & 345.54 & & 1.000 \\
\hline 2 & 5 & 74.56 & 64.14 & 178.83 & 19.13 & 0.535 \\
\hline 3 & 10 & 59.20 & 54.83 & 121.39 & 14.08 & 0.347 \\
\hline 4 & 15 & 52.50 & 49.07 & 96.34 & 6.63 & 0.265 \\
\hline 5 & 20 & 46.70 & 42.74 & 74.64 & 3.07 & 0.194 \\
\hline 6 & 30 & 40.40 & 33.00 & 49.25 & 2.07 & 0.111 \\
\hline 7 & 40 & 35.30 & 26.70 & 36.43 & 1.47 & 0.069 \\
\hline 8 & 55 & 30.60 & 21.40 & 27.23 & 1.28 & 0.036 \\
\hline 9 & 60 & 29.40 & 16.44 & 19.67 & 0.90 & 0.015 \\
\hline 10 & 72 & 26.92 & 13.20 & 15.21 & 0.29 & 0.000 \\
\hline
\end{tabular}

\begin{tabular}{|c|c|c|c|c|c|c|}
\hline \multicolumn{7}{|c|}{ Drying data for Soda dip treatment at $60^{\mathbf{0}} \mathbf{C}$} \\
\hline Sr. No & $\begin{array}{c}\text { Drying } \\
\text { time(hr) }\end{array}$ & $\begin{array}{c}\text { Weight of } \\
\text { sample(g) }\end{array}$ & $\begin{array}{c}\text { M.C. } \\
\text { (w.b.) }\end{array}$ & $\begin{array}{c}\text { M.C. } \\
(\mathbf{d . b} .)\end{array}$ & $\begin{array}{c}\text { Drying } \\
\text { rate }\end{array}$ & $\begin{array}{c}\text { Moisture } \\
\text { ratio }\end{array}$ \\
\hline 1 & 0 & 100.00 & 78.00 & 345.54 & & 1.000 \\
\hline 2 & 5 & 69.24 & 61.58 & 160.30 & 23.01 & 0.470 \\
\hline 3 & 10 & 55.46 & 51.20 & 104.92 & 12.57 & 0.290 \\
\hline 4 & 15 & 46.68 & 43.02 & 75.49 & 8.64 & 0.195 \\
\hline 5 & 20 & 40.40 & 36.50 & 57.48 & 2.02 & 0.137 \\
\hline 6 & 30 & $38 . .90$ & 27.76 & 38.42 & 2.25 & 0.075 \\
\hline 7 & 40 & 29.80 & 21.40 & 27.23 & 1.06 & 0.039 \\
\hline 8 & 55 & 27.60 & 16.56 & 19.85 & 0.48 & 0.015 \\
\hline 9 & 60 & 26.36 & 13.30 & 15.34 & 0.34 & 0.000 \\
\hline
\end{tabular}


Table.4 Drying data for Preyal dip treatment

\begin{tabular}{|c|c|c|c|c|c|c|}
\hline \multicolumn{7}{|c|}{ Drying data for Preyal dip treatment at 50 C } \\
\hline Sr. No & $\begin{array}{c}\text { Drying } \\
\text { time(hr) }\end{array}$ & $\begin{array}{c}\text { Weight of } \\
\text { sample(g) }\end{array}$ & $\begin{array}{c}\text { M.C. } \\
\text { (w.b.) }\end{array}$ & $\begin{array}{c}\text { M.C. } \\
(\mathbf{d . b .})\end{array}$ & $\begin{array}{c}\text { Drying } \\
\text { rate }\end{array}$ & $\begin{array}{c}\text { Moisture } \\
\text { ratio }\end{array}$ \\
\hline 1 & 0 & 100.00 & 78.00 & 345.54 & & 1.000 \\
\hline 2 & 5 & 73.72 & 63.73 & 175.68 & 19.76 & 0.556 \\
\hline 3 & 10 & 60.00 & 55.43 & 124.38 & 10.31 & 0.376 \\
\hline 4 & 14 & 52.60 & 49.16 & 96.71 & 6.69 & 0.284 \\
\hline 5 & 20 & 47.00 & 43.11 & 75.77 & 3.51 & 0.211 \\
\hline 6 & 30 & 39.80 & 31.00 & 44.93 & 2.71 & 0.105 \\
\hline 7 & 40 & 36.30 & 24.00 & 31.58 & 1.32 & 0.059 \\
\hline 8 & 60 & 30.80 & 16.70 & 20.05 & 0.59 & 0.19 \\
\hline 9 & 75 & 27.30 & 12.69 & 14.53 & 0.48 & 0.000 \\
\hline
\end{tabular}

\begin{tabular}{|c|c|c|c|c|c|c|}
\hline \multicolumn{7}{|c|}{ Drying data for Preyal dip treatment at $\mathbf{6 0}^{\mathbf{0}} \mathbf{C}$} \\
\hline Sr. No & $\begin{array}{c}\text { Drying } \\
\text { time(hr) }\end{array}$ & $\begin{array}{c}\text { Weight of } \\
\text { sample(g) }\end{array}$ & $\begin{array}{c}\text { M.C. } \\
\text { (w.b.) }\end{array}$ & $\begin{array}{c}\text { M.C. } \\
\text { (d.b.) }\end{array}$ & $\begin{array}{c}\text { Drying } \\
\text { rate }\end{array}$ & $\begin{array}{c}\text { Moisture } \\
\text { ratio }\end{array}$ \\
\hline 1 & 0 & 100.00 & 78.00 & 345.54 & & 1.000 \\
\hline 2 & 5 & 71.56 & 62.83 & 169.02 & 21.27 & 0.498 \\
\hline 3 & 10 & 53.74 & 50.50 & 102.03 & 13.33 & 0.280 \\
\hline 4 & 14 & 46.40 & 42.67 & 74.44 & 6.86 & 0.191 \\
\hline 5 & 20 & 42.24 & 35.40 & 54.80 & 2.59 & 0.127 \\
\hline 6 & 30 & 34.90 & 25.60 & 34.41 & 2.21 & 0.061 \\
\hline 7 & 40 & 31.10 & 19.73 & 24.59 & 1.20 & 0.029 \\
\hline 8 & 60 & 26.40 & 13.50 & 15.61 & 0.67 & 0.000 \\
\hline
\end{tabular}


Fig.1 Flow chart for the preparation of pre-treated raisins

\section{Grapes}

(Thompson Seedless)

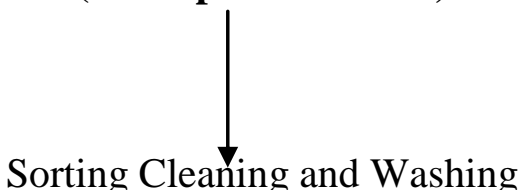

Sorting Cleaning and Washing

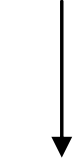

Pretreatments

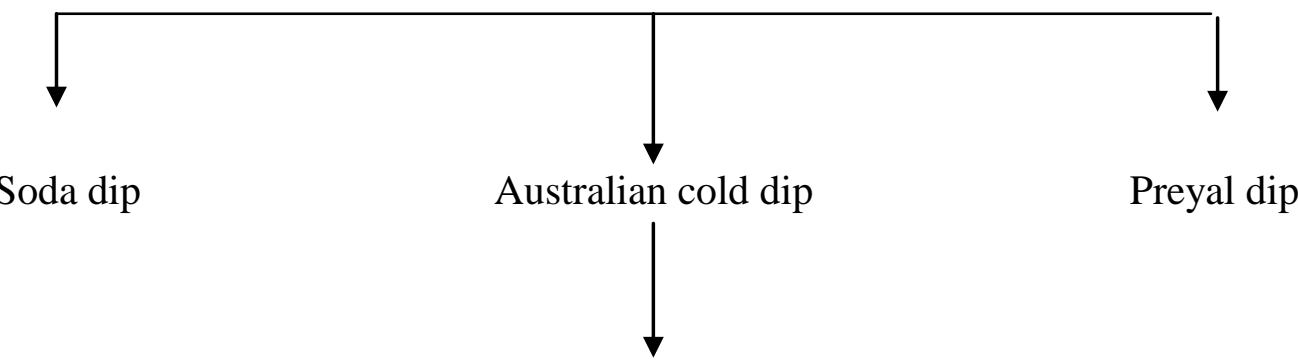

Rinsing in Cold Water

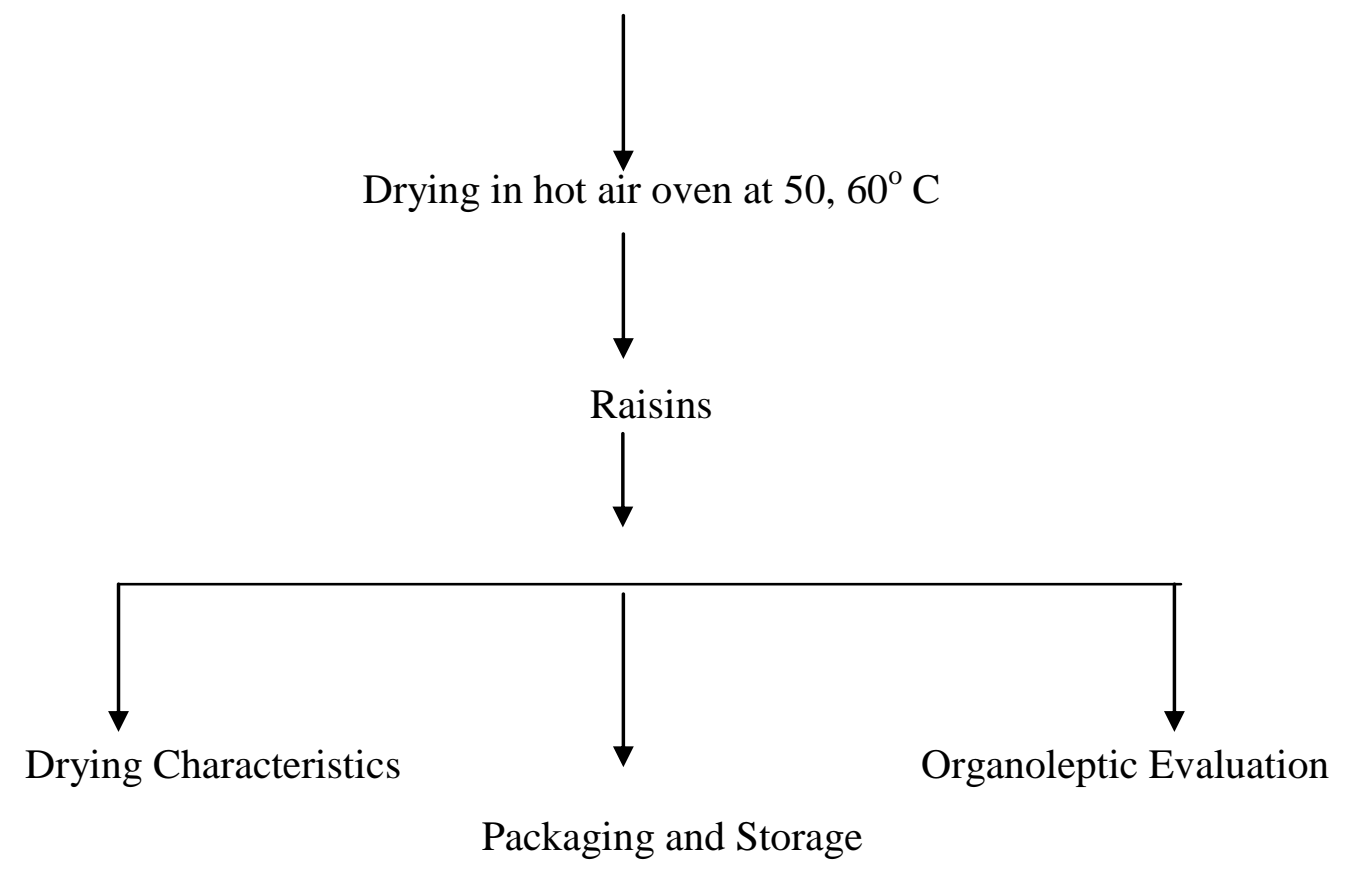


Fig.2 Effect of drying time on moisture content (without treatment)

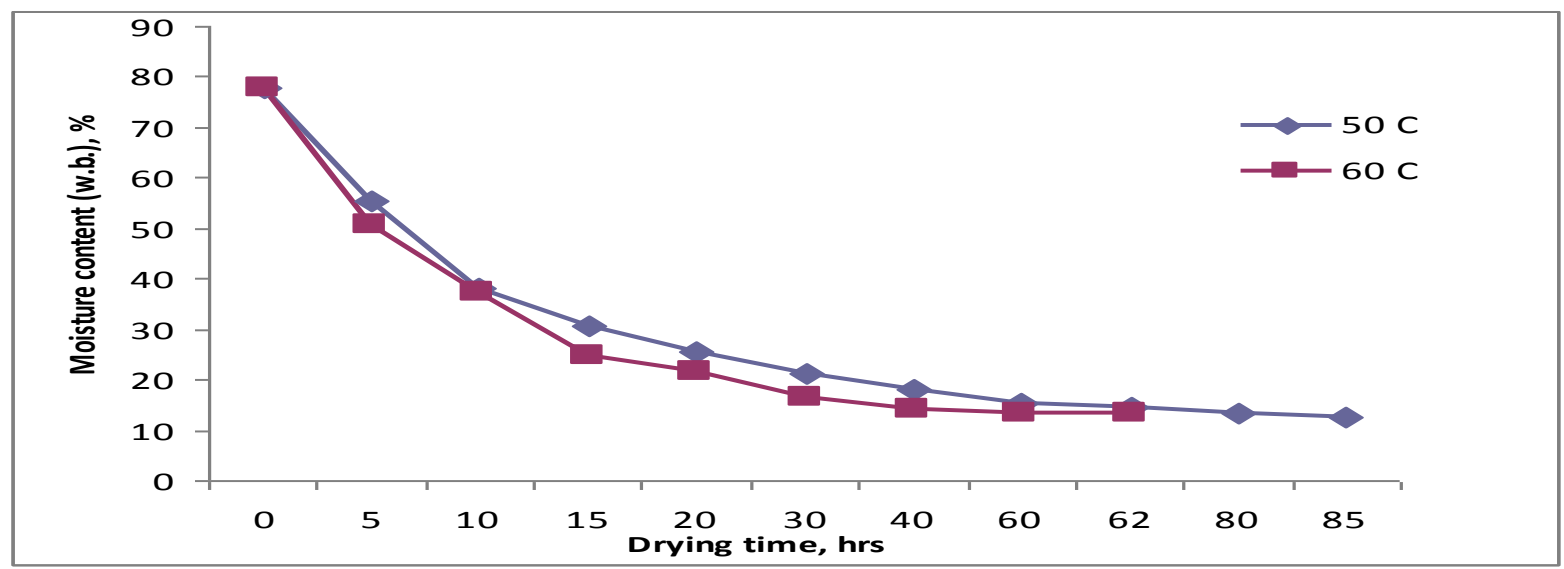

Fig.3 Effect of drying time on moisture content (Australian dip)

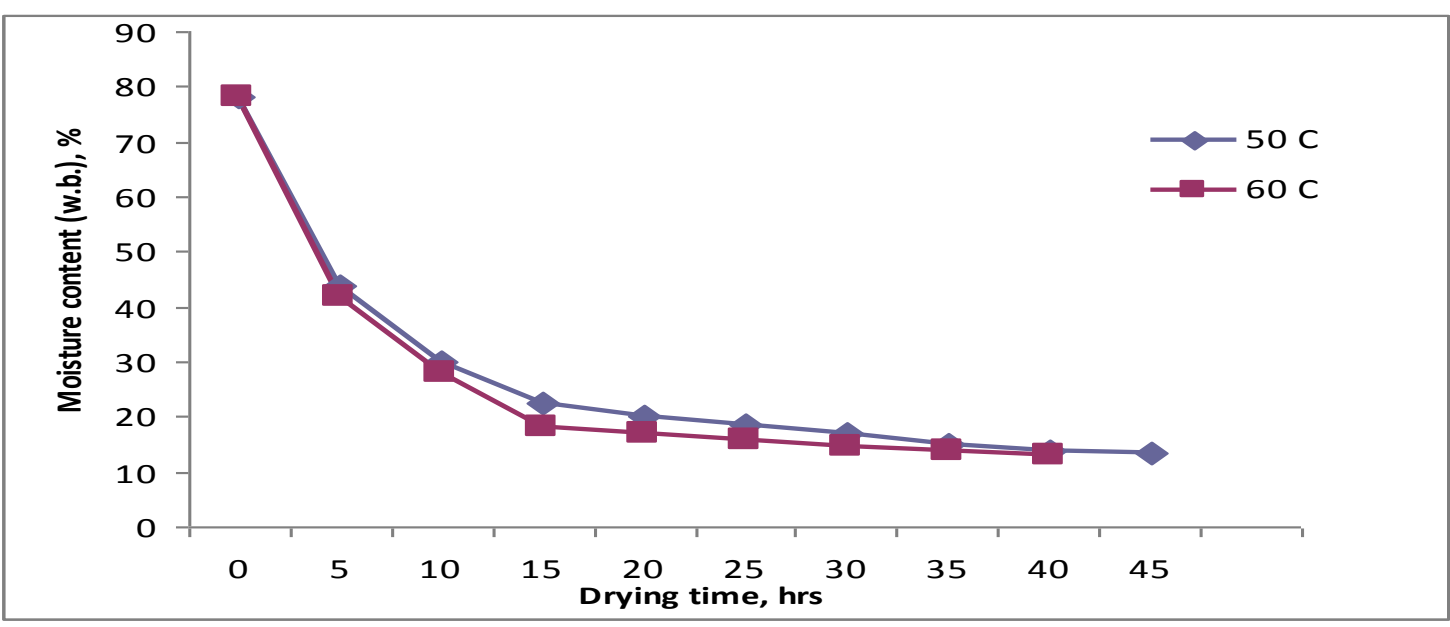

Fig.4 Effect of drying time on moisture content (Soda dip)

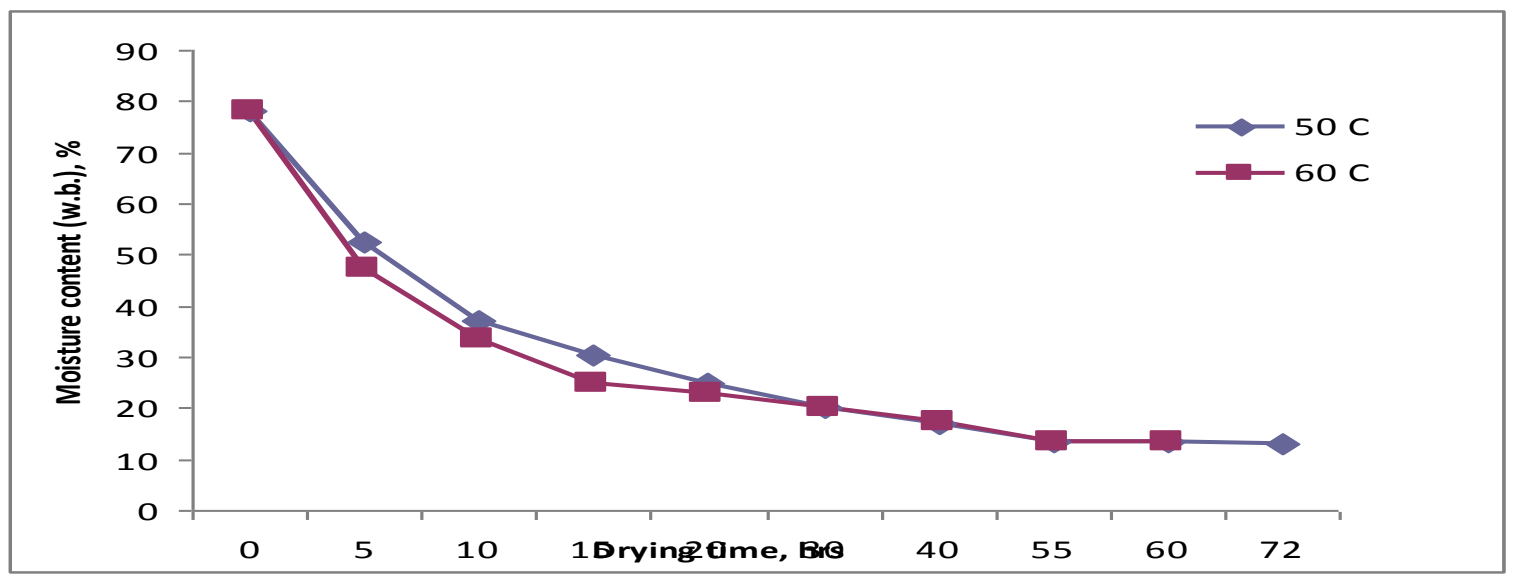


Fig.5 Effect of drying time on moisture content (Preyal dip)

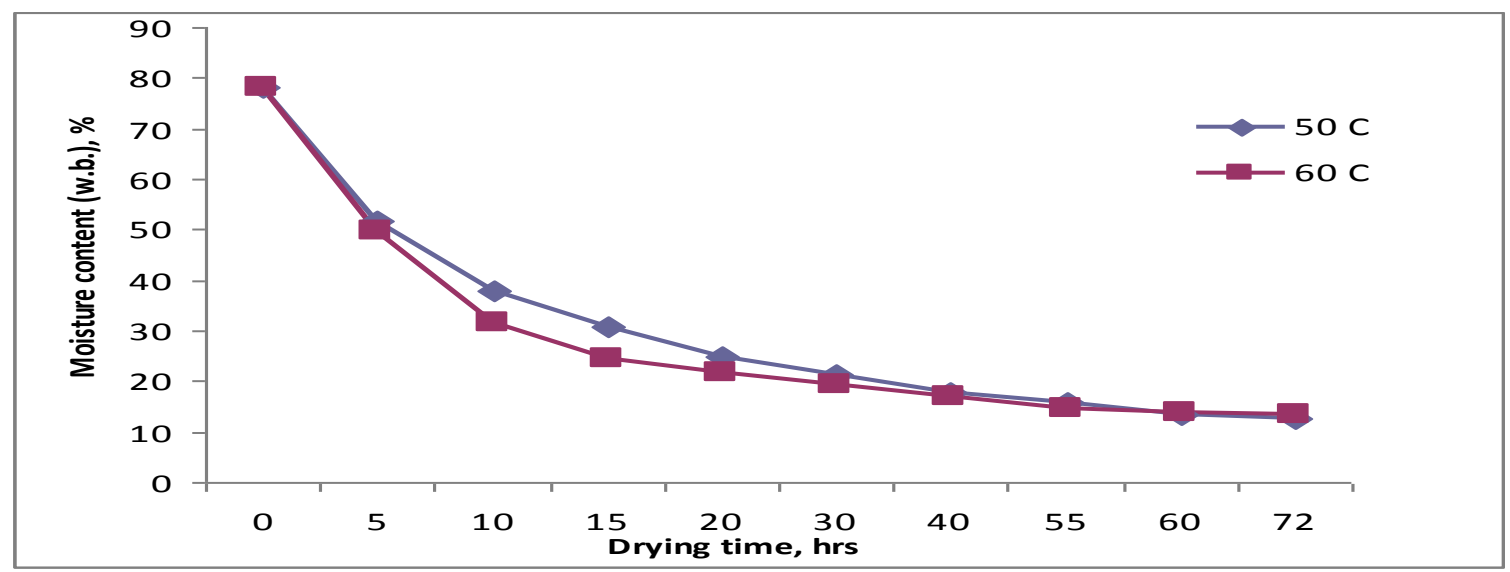

Fig.6 Effect of drying time on drying rate (without treatment)

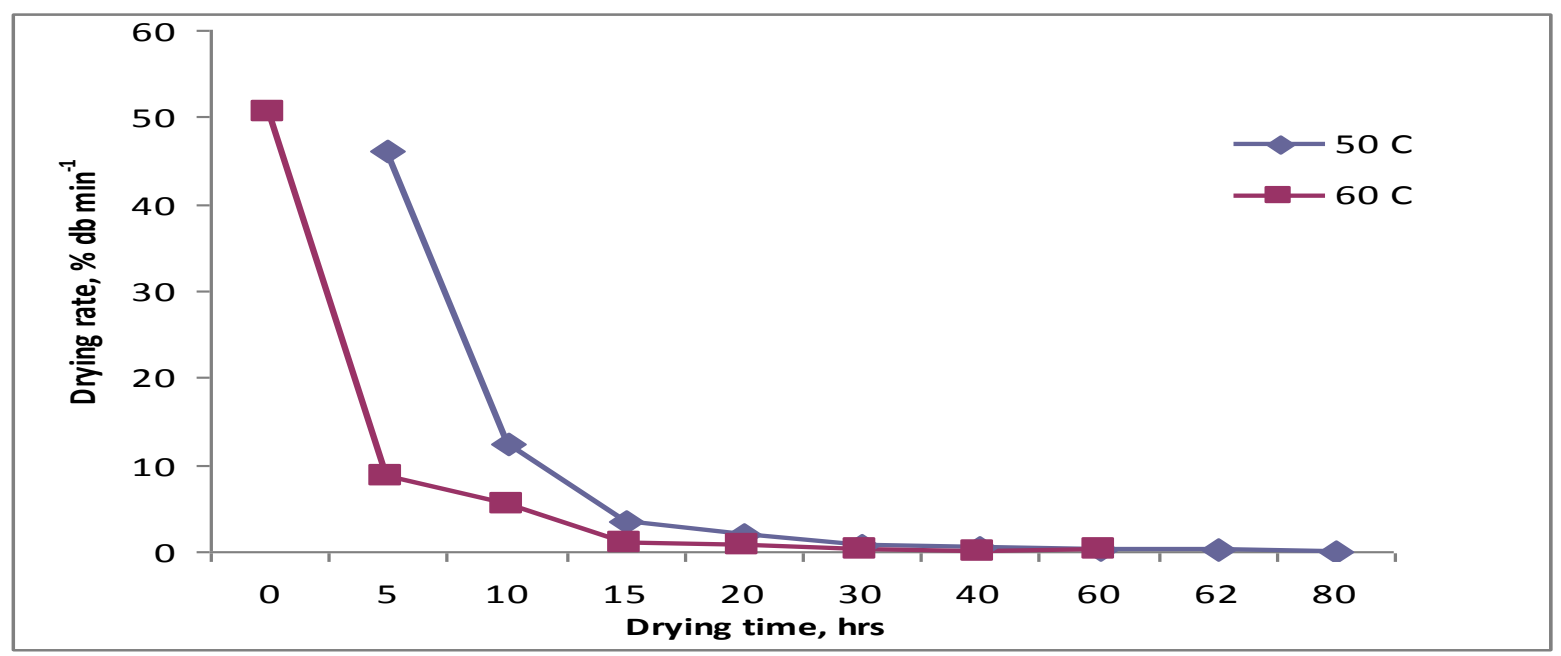

Fig.7 Effect of drying time on drying rate (Australian dip)

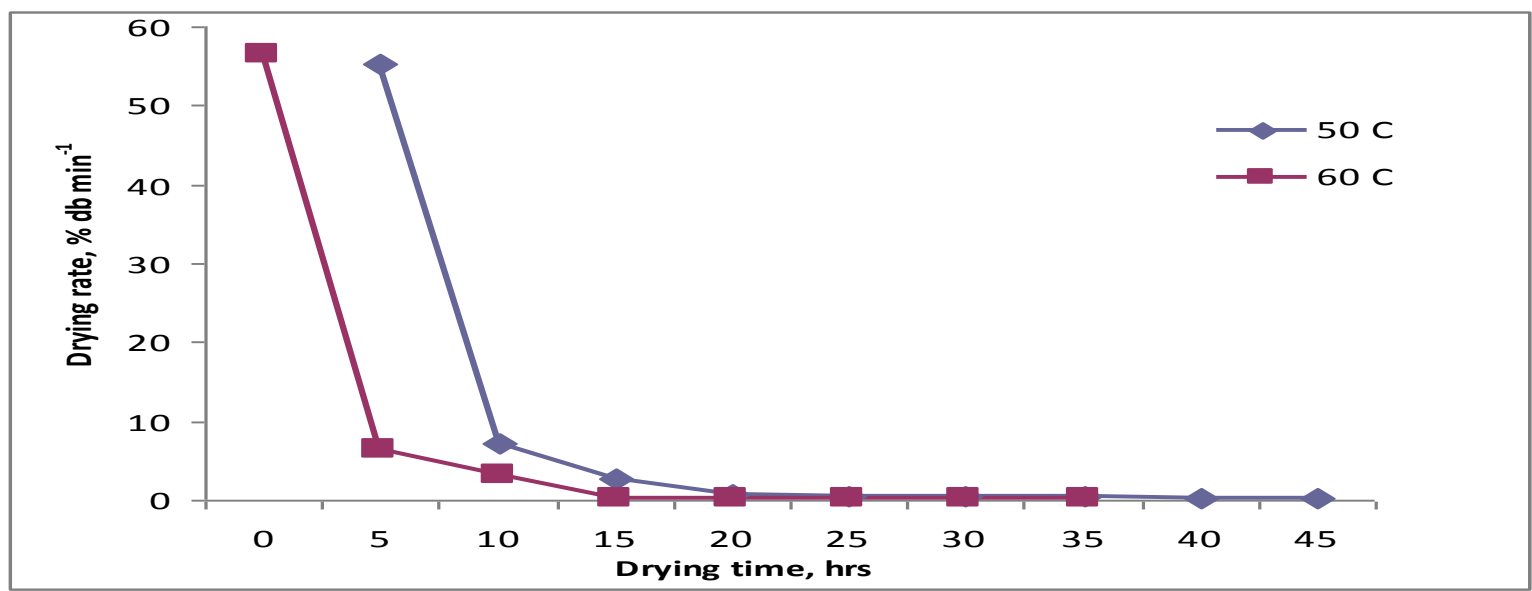


Fig.8 Effect of drying time on drying rate (Soda dip)

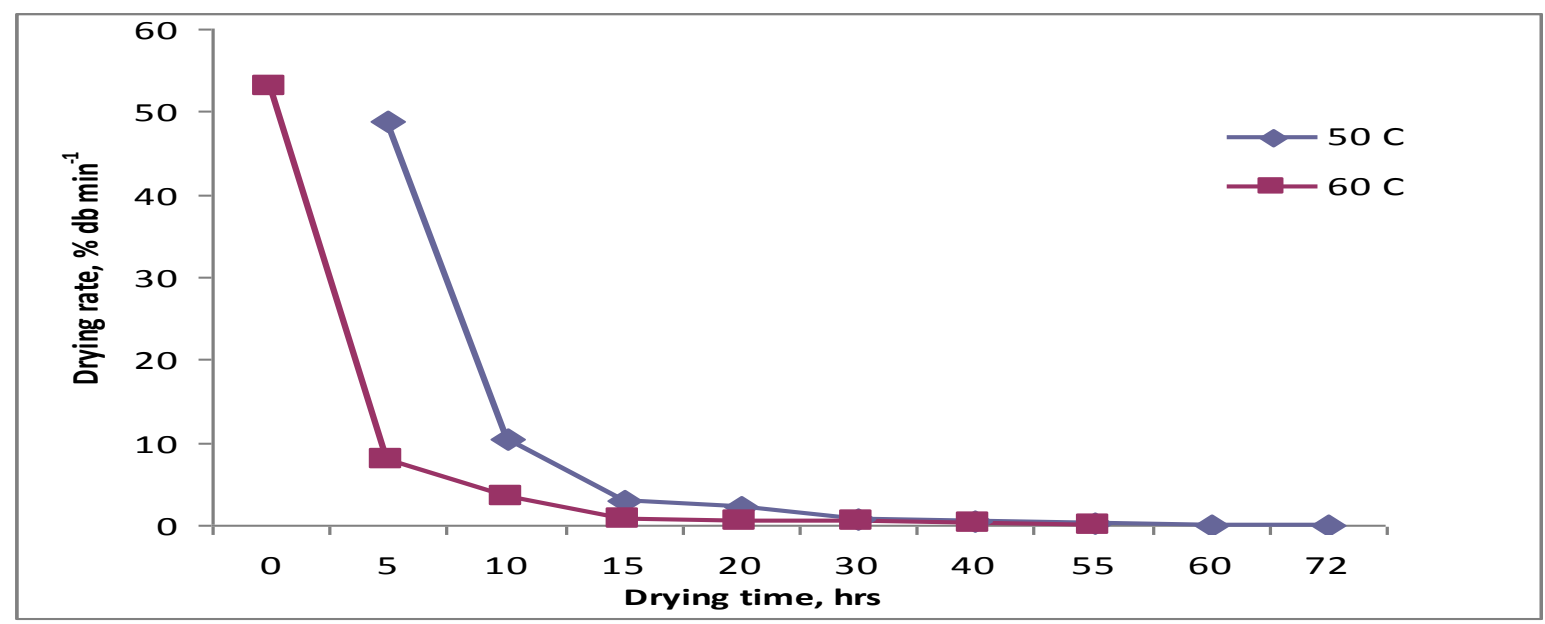

Fig.9 Effect of drying time on drying rate (Preyal dip)

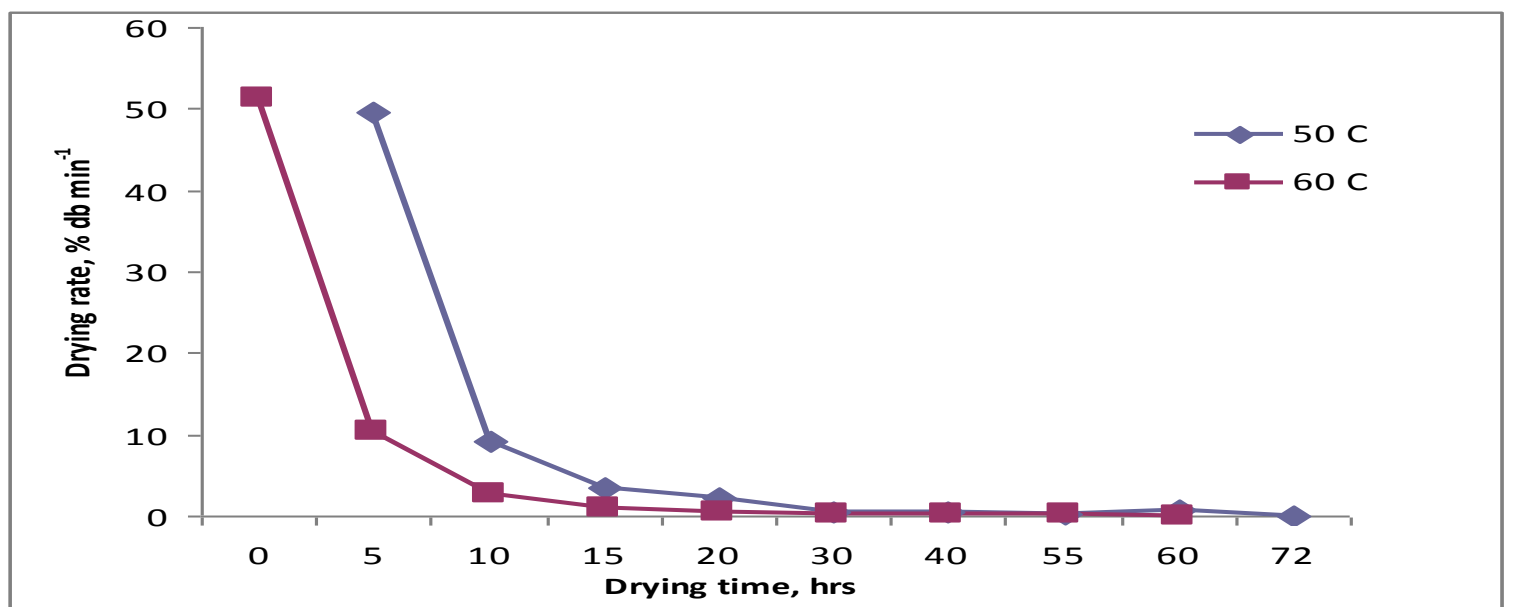

In conclusion, grapes (Vitis Vinifera L.) is one of the most important horticulture crop of Maharashtra. The per hector returns from grapes are probably the highest among all the horticultural crops. Grapes are good source of dietary sugars, organic acids and provide good amount of minerals like iron and phosphorus and some vitamins.

The production of grapes has increased considerably during the last few years. With increase in production, there is seasonal glut in the market and farmers are getting low price for their produce. Efforts have been made to exports the grapes produced do not meet the consumer requirements in the importing countries. It is therefore, necessary to develop suitable technology for processing of grapes, so that the excess production can be utilized more economically. The effect of pretreatments and drying temperature on chemical composition and organoleptic properties was seen. Based on the results given in chapter 4 , the following conclusion could be drawn

1. The grape berries (var.: Thompson seedless) were dried from 78 per cent (345.54 
per cent, d.b.) to 13.14 per cent (15.15 per cent, d.b.).

2. The total drying time of 40 to $51 \mathrm{hrs}, 60$ to $78 \mathrm{hrs}, 60$ to $80 \mathrm{hrs}$ was required for raisin making, when grapes are treated using Australian cold dip, soda dip, preyal dip methods respectively. Where as in case of control samples, total drying time of 60 to 96 hrs was required.

3. The drying rate varied between 26.04 to $0.12 \mathrm{~g} / \mathrm{hr}-100 \mathrm{gd} . \mathrm{b} . \mathrm{m}$. for all treatments.

4. The better quality raisins could be prepared from the grapes (var. Thompson seedless) by using Australian cold dip method and drying temperature $50^{\circ} \mathrm{C}$.

5. The average score for color, appearance, texture and taste of the raisins ranged between 5.6 to $8.6,5.5$ to 8.3 and 5.2 to8.1 respectively. The overall acceptability of the raisins made by using Australian cold dip, preyal dip, soda dip and control methods was found as 8.3,8.0,7.1 and 6.5 when grapes were dried at $50^{\circ} \mathrm{C}$. The minimum overall acceptability of the raisins made by using Australian cold dip, preyal dip, soda dip and control methods was found as 7.4, 6.8, 6.2 and 5.4 when grapes were dried at $60^{\circ} \mathrm{C}$.

6. Drying characteristics and organoleptic properties of raisins prepared by different methods the Australian cold dip method was found to be suitable for preparation of raisins.

\section{References}

Amba Dan, 1985. Production, Processing and storage aspects of raisin making in India. Proc. First National Workshop on Post-harvest Management of Grapes held at Pune, pp. 284-288.

Annonymous 2000. Raisin awareness www.foodproductdesign.com
Annonymous 2003 http://www.nabard.org/ roles $/ \mathrm{ms} / \mathrm{ph} / \mathrm{grapes} . \mathrm{htm}$

Annonymous.1980. Accelerated drying. A new raincoat for raisins. Agricultural research (Washington). 29(6): 12-14.

Arif, M. 1959 The Sun Drying Of Grapes. Alexandria J. Agric. Res. 7:89-102.

Bhutani, V.P., Negi T.C.P. and Chadha, T.R. 1980 Studies on raisin making under dry and temperate conditions. The Punjab Hort. J. 20(3/4): 203-206

Bolin H.R. and Stafford, A.E. 1980. Fatty acid esters and carbonates in grape drying J. Food Sci. 45 (3): 754 - 755

Chavan, U. D. adsulte, R.N. and Kadam, S.S. 1992. Raisins from gibberelic acid treated grapes. Drakshavritta. 12(6): 75 -76 .

Dhillon, W. S. 1994. production and post harvest technology of grapes. Drakshavritta. 14(6): 131 - 134.

Gawade, B.J., Naikare, S.M., Jadhav, M.S. and Bhujabal, B.G. 1994. The storage studies of Thompson Seedless Raisins Drakshavritta. 14(6): 173 - 176.

Gee, M. 1980 Some flavour and color changes during low temperature dehydration of grapes J. Food Sci. 45(1): $146-147$.

Kulkarni, A.P. 1984. Studies on drying and dehydration of grapes. M.Sc. Thesis Marathwada Krishi Vidyapeeth, Parbhani, (India).

Maini, S.B. Arve, S.D. Sagar, V.R. and Rajesh Kumar. 1994. Effects of pretreatments on the quality of dehydrated grapes. Drakshavritta 14 (6) $177-180$.

More, S.B. and Pagare, P.U. 1998 Studies on critical moisture content of fruits and vegetables B. Tech Thesis Mahatama Phule Krishi Vidyapeeth, Rahuri (India), pp 40 - 50.

Petrucci, V., Canata, N. Bolari, H.R., Fuller, G. and Stafford, A.G. 1974 Uses of oleic acid to accelerate drying of 
Thompson Seedless Grapes J. Am. Oil. Chemist Soc. 51(3): $77-80$.

Radller, F. 1965 Reduction of loss of moisture cuticle wax content of grapes nature. 207: $1002-3$.

Shikhamany, S.D. 2004. Grape production in India. www.fac.org

Singh, J.P. and Dhavan, S.S., 1973. Use of solar heat for raisin making. Indian
Hort. 18(1): $10-11$.

Thorat, A.K., Bhatiya B.S., Kuppuswami, S. and Bhatiya, D.S. 1963. Further studies on drying of Indian grapes. Food Sci. 12(4): 97 - 114.

Wrinkler, A.J. 1962 General viticulture, University of Calfornia Press, Berkeley, USA, pp. $543-577$.

\section{How to cite this article:}

Sardar, N.R., Tiwari Manish, G.P. Tagalpallewar, J.P. Rathod and Butti Prabhakar. 2019. Effect of Various Pretreatments on Raisin Making from Grapes (Vitis vinifera L.). Int.J.Curr.Microbiol.App.Sci. 8(05): 575-587. doi: https://doi.org/10.20546/ijcmas.2019.805.067 